\title{
PENGENDALIAN LIMBAH BUDIDAYA PERIKANAN MELALUI PEMANFAATAN TUMBUHAN AIR DENGAN SISTEM CONSTRUCTED WETLAND
}

\author{
Erlania \\ Pusat Penelitian dan Pengembangan Perikanan Budidaya \\ Jl. Ragunan 20, Pasar Minggu, Jakarta Selatan 12540 \\ E-mail: erlania_elleen@yahoo.com
}

\begin{abstract}
ABSTRAK
Berkembangnya kegiatan usaha budidaya menyebabkan semakin besarnya masukan limbah organik ke perairan. Pengolahan limbah organik pada dasarnya tidak membutuhkan biaya yang tinggi. Konsep pengolahan air limbah menggunakan media tumbuhan air atau yang lebih populer dengan istilah fitoremediasi sangat efektif digunakan. Proses fitoremediasi ini diterapkan dalam bentuk sistem constructed wetland. Dalam sistem ini, tumbuhan air menyerap bahan organik dari limbah budidaya yang dimanfaatkan untuk proses pertumbuhannya. Selain itu, tumbuhan air juga dapat menyerap kandungan logam berat yang terdapat dalam air. Pemanfaatan tumbuhan air untuk pengolahan limbah tidak membutuhkan biaya yang besar dan teknik khusus dalam pemeliharaannya, serta dapat memberikan nilai tambah lainnya. Selain tidak memerlukan bahan kimia yang dapat membahayakan lingkungan, juga dapat dipanen dan dimanfaatkan sebagai pupuk, pakan ternak, kerajinan tangan, dan memberikan nilai estetika pada area pengo lahan limbah.
\end{abstract}

KATAKUNCl: pengendalian, limbah budidaya, tumbuhan air, constructed wetland

\section{PENDAHULUAN}

Dalam rangka mewujudkan visi Kementerian Kelautan dan Perikanan (KKP) untuk menjadikan Indonesia sebagai penghasil produk kelautan dan perikanan terbesar tahun 2015, maka KKP menargetkan peningkatan produksi hingga 353\%pada tahun 2014. Dalam proses peningkatan produksi tersebut, khususnya oleh sektor perikanan budidaya, juga akan menyebabkan terjadinya peningkatan "hasil sampingan" dari kegiatan budidaya tersebut berupa limbah. Untuk mencegah terjadinya kerusakan lingkungan akibat peningkatan volume limbah yang dihasilkan, diperlukan suatu bentuk kegiatan budidaya yang dilengkapi dengan sistem pengolahan limbahnya.
Konsep pengolahan air limbah menggunakan media tumbuhan air atau yang lebih populer dengan istilah fitoremediasi sudah lama dikenal. Akan tetapi terapi lingkungan dengan cara ini masih kurang "diminati" oleh masyarakat sebagai solusi pemecahan masalah lingkungan yang semakin lama akan menjadi permasalahan yang kronis. Di sisi lain, pengolahan limbah menggunakan bahan-bahan kimia justru membutuhkan biaya yang sangat tinggi, bahkan terkadang melebihi biaya produksi suatu produk tertentu, sehingga sebagian masyarakat lebih memilih untuk tidak melakukan pengolahan limbah terlebih dahulu sebelum limbah tersebut dibuang ke lingkungan sekitarnya. Akibatnya semakin lama terjadi penurunan kualitas lingkungan yang berdampak pada penurunan kualitas dan kuantitas produk budidaya itu sendiri. Konsep pengolahan limbah dengan prinsip fitoremediasi ini biasanya diterapkan dengan membangun sebuah ekosistem buatan yang berfungsi sebagai pengolahan air limbah, yang dikenal dengan sistem constructed wetland (Crites et al., 1988).

Menurut Departement of Natural Resources, State of Georgia (2002), constructed wetland merupakan suatu sistem pengolahan air limbah secara alami dengan konstruksi yang sederhana serta membutuhkan biaya operasional dan pemeliharaan yang lebih murah dibandingkan sistem pengolahan air limbah dengan mekanisme konvensional. Constructed wetland terdiri atas sebuah kolam yang didesain secara layak, yang di dalamnya terdapat air limbah, substrat dan tumbuhan air, serta termasuk saluran pembuangan air ke perairan umum.

Dalam Anonimous (1976), dinyatakan juga bahwa metode pengolahan limbah ini dapat diterapkan untuk berbagai skala/ukuran pengolahan limbah sesuai dengan kebutuhan, misalnya untuk pengolahan limbah pemukiman, pertanian, maupun perkotaan. Selain itu, tumbuhan air tertentu juga dapat membantu menghilangkan bahanbahan berbahaya dari air minum, seperti cadmium, nikel, merkuri, fenol dan bahan-bahan yang bersifat karsinogenik. Bahan-bahan tersebut akan diserap dari air dan dikonsentratkan hingga menjadi 4.000-20.000 kali lebih konsentrat di dalam tumbuhan tersebut daripada di air. 


\section{PERANAN TUMBUHAN AIR DALAM PROSES PURIFIKASI AIR LIMBAH}

Fitoremediasi merupakan suatu proses menggunakan jenis tanaman tertentu yang bekerjasama dengan mikroorganisme dalam media, untuk mengubah bahan pencemar menjadi kurang atau tidak berbahaya, bahkan menjadi bahan yang berguna secara ekonomis (Anonimous, 2003).

Menurut Boyd (1970), pemilihan tipe tumbuhan air sebagai penyerap atau perangkap nutrien yang potensial membutuhkan beberapa kriteria, antara lain :

a. Kecepatan tumbuh yang tinggi

b. Dapat memproduksi biomassa yang besar dalam luasan tertentu

c. Dapat menimbun mineral atau nutrien yang banyak

d. Relatif mudah dipanen

e. Mempunyai nilai nutrisi yang cukup untuk pakan dan juga bisa dimanfaatkan sebagai pupuk

Anonimous (1976) melaporkan bahwa tidak semua tumbuhan air dapat hidup pada air limbah. Di antara spesies yang dapat beradaptasi dan tumbuh dengan baik yaitu Phragmites communis, Scirpus lacustris, Lemna spp., Spirodela spp., Elodea canadensis, Egeria densa, Hydrilla dan Ceratophyllum demersum. Menurut The National Space Technology Laboratories, Eichhornia crassipes (eceng gondok) dan Alternanthera philoxeroide (alligator weeds) memiliki kemampuan untuk menghilangkan/menyerap polutan dari limbah rumah tangga dan limbah industri.

Senyawa nitrogen dan fosfor merupakan senyawa yang umum ditemukan sebagai polutan di perairan. Beberapa jenis tumbuhan air dapat mengekstrak material tersebut dari air dan menggabungkannnya menjadi senyawa dengan struktur tertentu. Peneliti dari sejumlah laboratorium penelitian telah menemukan bahwa tumbuhan air dapat digunakan dalam proses pengolahan air limbah, sehingga nutrien yang terlarut dalam air limbah dapat dimanfaatkan kembali (Anonimous, 1976).

Widjaja (2004) mengatakan bahwa tumbuhan air dapat meningkatkan proses pengendapan lumpur di air. Lumpur tersangkut pada akar-akarnya, sehingga secara tidak langsung terjadi pengendapan lumpur yang dapat menjernihkan air. Proses refining (penjernihan) terutama dilakukan oleh tumbuhan tenggelam terhadap ion lumpur yang bermuatan negatif (de-ionisasi lumpur).

Menurut Widjaja (2004), dalam proses penjernihan air, tumbuhan menyerap unsur hara yang berlebihan di dalam air. Oleh sebab itu, tumbuhan air juga dapat berfungsi sebagai pengatur daur unsur hara dalam air secara berimbang, misalnya eceng gondok dapat menyerap logam beracun $(\mathrm{Pb}, \mathrm{Hg})$, logam penyebab kanker $(\mathrm{Ni}, \mathrm{Cd})$, cemaran organik (senyawa fenol, dan lain-lain), buangan pertanian (sisa pupuk, pestisida), buangan industri ( $\mathrm{Pb}$, $\mathrm{Ni}, \mathrm{Cl}$, dan lain-lain) serta buangan rumah tangga ( $\mathrm{N}, \mathrm{P}$, dan lain-lain). Eceng gondok dapat menjerat N sebanyak 313- $777 \mathrm{~kg} / \mathrm{ha} /$ tahun atau sama dengan buangan penduduk sebanyak 70-190 orang/tahun, P sebanyak 96-230 kg/ha/tahun atau sama dengan buangan penduduk sebanyak 70-175 orang/tahun. Scirpus lacustris diketahui mempunyai kemampuan untuk "menghilangkan" bakteri dan mikroorganisme lain serta detritus organik dari dalam air.

Khiatuddin (2003) menyatakan bahwa tumbuhan air berperan dalam mendukung kehidupan mikroorganisme pengurai limbah seperti bakteri, jamur, alga, dan protozoa, di mana tumbuhan air dapat mengeluarkan oksigen ke dalam tanah/substrat di dasar air melalui akarnya, sehingga akan terbentuk zona rizosfer yang kaya oksigen di seluruh permukaan rambut akar. Hasil percobaan Brix et al. (1992) in Khiatuddin (2003) menunjukkan bahwa tumbuhan air mampu memasok oksigen ke dalam tanah di bawah permukaan air dalam kisaran antara $0,2->10 \mathrm{~cm}^{3}$ per batang per menit. Di antaranya Phragmites australismampu melepaskan sekitar $5,3 \mathrm{~cm}^{3}$ oksigen per batang dalam satu menit. Dalam hal ini terdapat hubungan yang saling mendukung antara mikroorganisme dengan tumbuhan air, di mana mikroorganisme membutuhkan suplai oksigen dari akar tumbuhan untuk menguraikan bahan pencemar, sedangkan tumbuhan membutuhkan mikroorganisme untuk menguraikan bahan pencemar menjadi unsur hara yang didapat oleh tumbuhan (Khiatuddin, 2003).

\section{MEKANISME PURIFIKASI AIR LIMBAH PADA SISTEM CONSTRUCTED WETLAND}

Sistem constructed wetland pada umumnya sudah banyak dimanfaatkan pada pengolahan limbah pemukiman di negara-negara maju. Air limbah yang masuk ke dalam konstruksi kolam atau danau akan mengalami proses purifikasi secara fisika, kimia, dan biologi. Akar-akar tumbuhan dapat membantu proses pengendapan bahan pencemar yang berupa partikel/padatan yang terkandung dalam air limbah. Air limbah akan tertahan beberapa waktu pada wetland sebelum mengalir keluar. Tumbuhan dan mikroorganisme yang terdapat pada sistem tersebut akan menyerap dan menguraikan bahan-bahan pencemar. Kandungan bahan pencemar pada limbah sebagian besar merupakan nutrien bagi tumbuhan yang bermanfaat untuk pertumbuhannya walaupun sebaliknya dapat membahayakan bagi lingkungan. 
Menurut Khiatuddin (2003), efek pencemaran yang terjadi akan akan semakin berkurang dari bagian hulu tempat masuknya air tercemar hingga ke bagian hilir tempat air keluar. Oleh karena itu, dalam penerapan sistem constructed wetland untuk pangolahan air limbah perlu dilakukan penataan lahan sedemikian hingga, agar air yang keluar dari sistem tersebut dapat terpurifikasi seoptimal mungkin.

Secara umum, proses pengolahan air limbah terdiri atas tiga tahapan (Smith, 2007) yaitu:

- Primary treatment, yaitu penghilangan partikel-partikel kasar dengan cara pengendapan

- Secondary treatment, yaitu penghilangan mikroorganisme patogen, nutrien, senyawa organik, dan logam berat

- Tertiary treatment, berupa perlakuan tambahan (bila perlu) sebelum air dibuang atau dimanfaatkan kembali

Proses yang terjadi pada pengolahan air limbah dengan sistem constructed wetland sebenarnya tidak jauh berbeda dengan pengolahan air limbah menggunakan sistem konvensional. Keduanya mempunyai tujuan yang sama yaitu menghilangkan atau menurunkan konsentrasi polutan sehingga air dapat dimanfaatkan kembali atau dibuang ke lingkungan tanpa menyebabkan degradasi lingkungan serta tidak membahayakan bagi masyarakat di lingkungan tersebut. Perbedaannya hanya pada komponen yang digunakan pada kedua sistem tersebut. Sistem constructedwetland menggunakan tumbuhan air dan mikroorganisme sebagai agen yang berperan dalam proses purifikasi air limbah.

Pada dasarnya proses yang terjadi pada wetland sangat alami, artinya mikroorganisme dan tumbuhan membentuk ekosistem sendiri untuk berhadapan dengan jenis polutan yang masuk, sehingga tingkat adaptasi/akomodasi terhadap zat dan kadar pencemaran sangat baik. Berbeda dengan pengolahan limbah pada kolam fakultatif (facultative pond), proses purifikasi akan terganggu (invalid) jika ada limbah B3 (bahan beracun berbahaya) yang masuk atau jika beban pencemaran meningkat lebih dari $20 \%$ Hal ini dapat menyebabkan terjadinya blooming alga (Departemen Kimpraswil, 2003).

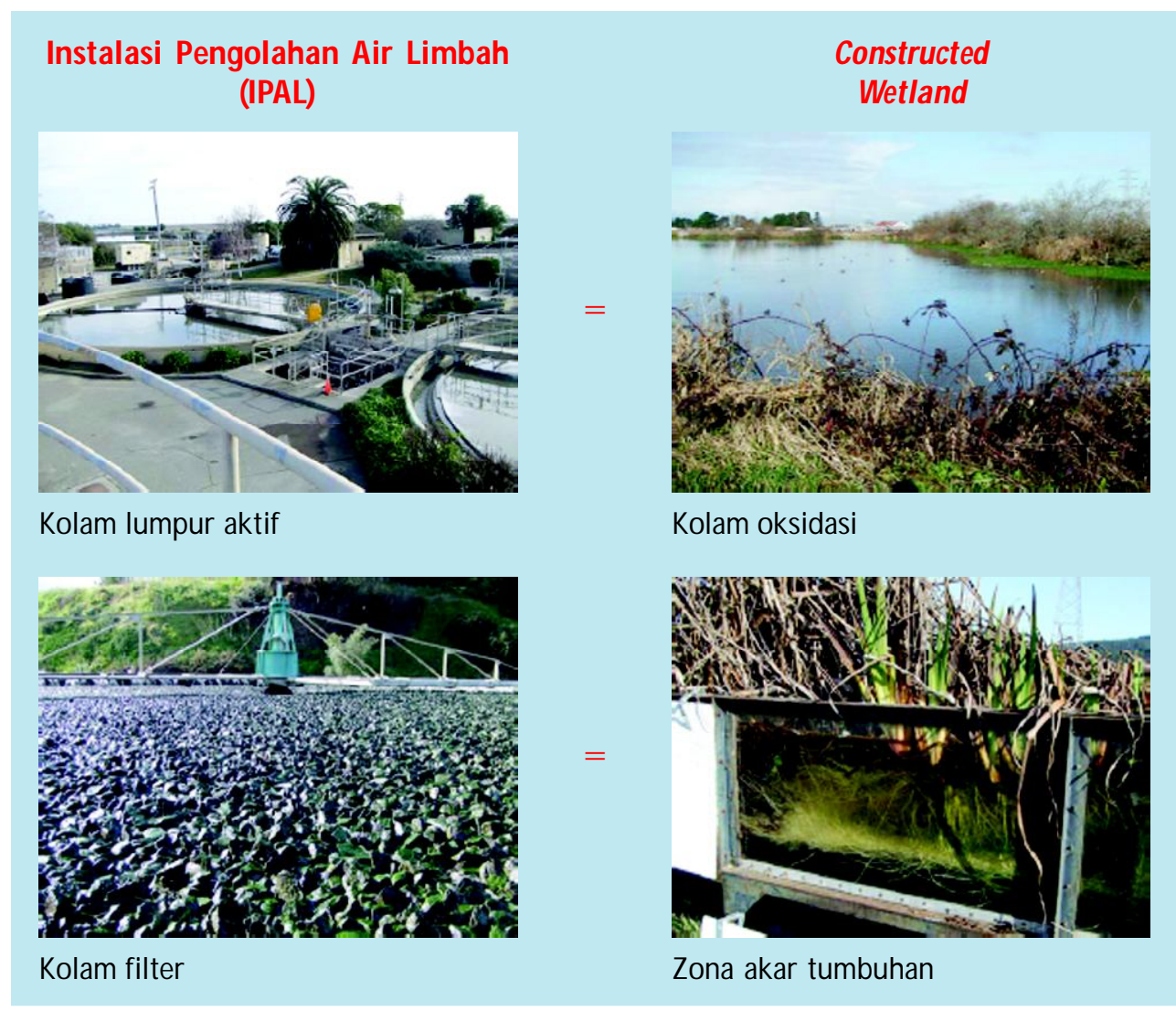

Sumber : Smith (2007)

Gambar 1. Perbandingan proses yang terjadi pada pengolahan limbah konvensional (IPAL) dengan constructed wetland 
Pada Gambar 1 dapat dilihat bahwa pada kolam lumpur aktif dan kolam oksidasi terjadi dua proses dengan tujuan yang sama. Pada kolam lumpur aktif, oksigen dipompa ke dalam air untuk menjaga ketersediaan mikroorganisme sebagai pengurai bahan organik. Sedangkan pada kolam oksidasi, dengan konstruksi kolam yang dangkal memungkinkan terjadinya aerasi pada kolam. Selain itu, juga didukung dengan adanya angin dan al ga yang dapat meningkatkan ketersediaan oksigen bagi mikroorganisme pengurai.

Demikian juga halnya kesamaan proses yang terjadi pada kolam filter dan zona akar tumbuhan. Pada kolam filter digunakan biofilm pada permukaan air kolam yang cukup luas agar terjadi lebih banyak perombakan bahan organik, baik secara aerob maupun anaerob. Sedangkan zona akar tumbuhan menciptakan kondisi yang memungkinkan bagi bakteri untuk menguraikan bahan organik, baik secara aerob (nitrifikasi) maupun anaerob (denitrifikasi).

Beansley (2003) menyebutkan bahwa untuk membuat desain wetland yang efektif, perlu diperhatikan faktor mikrotopografi untuk mendukung penataan keanekaragaman tumbuhan dan treatment area. Menurut Beansley (2003), desain pengolahan limbah yang mencirikan sistem constructed wetland di antaranya adalah:
- Forebays, berupa kolam dalam untuk proses sedimentasi yang terletak di bagian tengah wetland, bertujuan untuk mengurangi kecepatan masuknya air limpasan, memungkinkan proses pengendapan awal dari partikel polutan serta menyediakan area yang mudah terjangkau untuk pembuangan akumulasi sedimen selama waktu pemeliharaan.

- Long flow paths, berupa saluran panjang yang berfungsi sebagai tempat aliran air limbah menuju kolam sedimentasi. Saluran ini didesain sedemikian hingga untuk memperpanjang waktu kontak antara kontaminan dengan area permukaan wetland.

- Micropool, berupa kolam kecil sebelum outlet yang berfungsi untuk mencegah terjadinya penyumbatan outlet oleh serasah/debris serta memungkinkan pembuangan sisa-sisa polutan yang masih tertinggal dari wetland.

- Low and high marshes, bertujuan untuk penyediaan tingkatan elevasi tanah yang memungkinkan pertumbuhan vegetasi vital dan meningkatkan diversitas vegetasi pada wetland.

Desain tersebut merupakan struktur dasar yang seharusnya terdapat pada sebuah sistem constructed wetland, di mana penataan tersebut didasarkan pada

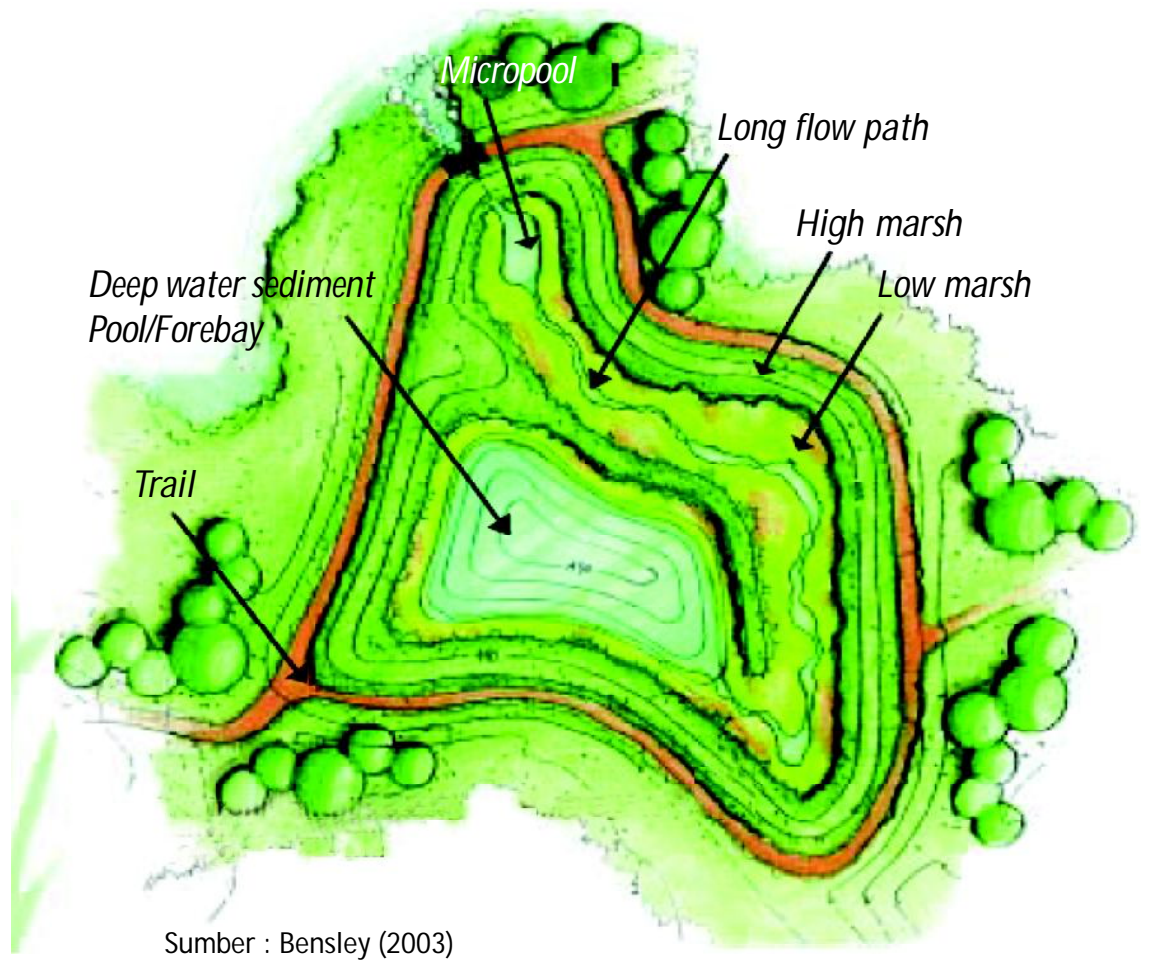

Gambar 2. Desain pengolahan limbah yang mencirikan sistem constructed wetland 
optimalisasi sistem dalam proses purifikasi limbah hingga air dapat dialirkan kembali ke lingkungan.

\section{TUMBUHAN AIR POTENSIAL UNTUK PENGOLAHAN AIR LIMBAH}

Secara garis besar, tumbuhan air dibagi atas tiga golongan, yaitu emergent (berakar di dasar sedangkan daun dan sebagian batang mencuat ke atas permukaan air), submerged (melayang di bawah permukaan air atau tenggelam di kolom air) serta floating (mengapung bebas maupun berakar di dasar dengan daun di permukaan air).

Tumbuhan air yang berakar di dasar dapat berperan sebagai stabilisator bagi dasar perairan. Tumbuhan air juga dapat berfungsi sebagai perangkap bahan organik pada perairan eutrofik. Tumbuhan air tertentu mempunyai sifat luxury uptake, yaitu aktif atau mampu menyerap zat atau nutrisi tertentu melebihi kebutuhannya (Widjaja, 2004).

Tumbuhan air mencuat (emergent type) dikenal sebagai tumbuhan yang paling produktif dari semua tumbuhan di dunia (Moss, 1980). Menurut Widjaja (2004), bila dibandingkan dengan tipe tumbuhan air yang lain, tipe mencuat dengan daun yang tinggi lurus memerlukan lahan yang lebih sedikit, sehingga dapat mengurangi penggunaan lahan serta lebih ekonomis dan efisien secara ekologis, yang artinya tumbuhan air tipe mencuat baik jika digunakan sebagai penyerap nutrien.

Menurut Brown et al. (1995), tumbuhan air yang memiliki sifat hipertoleran terhadap logam berat merupakan kunci dari karakteristik yang mengindikasikan sifat hiperakumulatornya. Tumbuhan dapat disebut hiperakumulator jika memiliki karakteristik sebagai berikut :

a. Tumbuhan memiliki tingkat laju penyerapan unsur tertentu dari lingkungannya melebihi jenis tumbuhan lainnya

b. Tumbuhan dapat mentolerir suatu unsur dalam tingkat yang tinggi pada jaringan akar dan tajuknya

c. Tumbuhan memiliki laju translokasi logam berat dari akar ke tajuk yang tinggi sehingga akumulasinya pada tajuk lebih tinggi daripada akar

Beberapa di antara jenis-jenis tumbuhan air yang potensial digunakan dalam proses pengolahan air limbah antara lain :

Typha spp.

Berdasarkan hasil studi oleh Roberts (1982) pada Typha spp. memperlihatkan standing crop sebesar $1.316 \mathrm{~g}$ bobot kering $/ \mathrm{m}^{2}$, yang sebanding dengan hasil yang dilaporkan oleh Mc Naughton (1966) yaitu $1.336 \mathrm{~g}$ bobot kering $/ \mathrm{m}^{2}$. Melihat tingginya produktivitas, maka tumbuhan ini dinilai efektif untuk pengolahan air limbah, di mana tingginya kemampuan penyerapan bahan organik dan jenis polutan lain sebanding dengan produktivitasnya.

Eichhornia crassipes (Water Hyacinth)

E. crassipes atau yang lebih dikenal dengan nama eceng gondok telah "dibudidayakan" pada kolam air limbah kota Lucedale, Mississippi, USA oleh The National Space Technology Laboratories. Hasil penelitian dari Universirty of Florida dan The Texas State Departement of Health Resources menunjukkan bahwa populasi $\mathrm{E}$. crassipes meningkat dalam jumlah fenomenal yakni 15\%dari luas area per hari selama musim panas. Dalam kondisi ini E. crassipes dapat dipanen 20-40 ton per hektar per hari, dengan mereduksi limbah nitrogen yang berasal lebih dari 2.000 orang dan limbah fosfor lebih dari 800 orang. Populasi E. crassipes menjadi dua kali lipat dalam waktu 6- 7 hari selama bulan Maret hingga November di Florida. Air limbah yang dilewatkan pada kolam rata-rata 2,2 juta liter per hektar per hari, E. crassipes yang tumbuh pada kolam tersebut dapat mereduksi $80 \%$ dari senyawa nitrogen dan 40\%dari senyawa fosfor yang terdapat dari air limbah tersebut dalam waktu 2 hari (Anonimous, 1976).

Alternanthera philoxeroides (Alligator weed)

Tumbuhan air yang dikenal dengan nama umum Alligator weed ini termasuk ke dalam famili Amaranthaceae. Tumbuhan ini sudah diteliti potensinya dalam menghilangkan logam berat $\mathrm{Hg}$ dan $\mathrm{Pb}$ dari air yang tercemar (Csurhes \& Markula, 2010).

Lemna sp., Pharagmites sp., Azolla sp., Scirpus sp., Iris sp., dll.

Jenis-jenis tumbuhan ini telah digunakan untuk menurunkan kandungan nutrien pada perairan yang tercemar semenjak diketahui bahwa tumbuhan tersebut memiliki kemampuan dalam menyerap nutrien dengan cepat. Penggunaan jenis-jenis tersebut dalam pengolahan limbah, baik secara alami maupun buatan, saat ini semakin mendapat banyak perhatian. Selain jenis-jenis tersebut masih banyak jenis tumbuhan air lainnya yang potensial untuk dimanfaatkan dalam proses pengolahan air limbah.

Kemampuan beberapa jenis tumbuhan air dalam menyerap bahan-bahan cemaran dari air limbah ditunjukkan pada Tabel 1. 


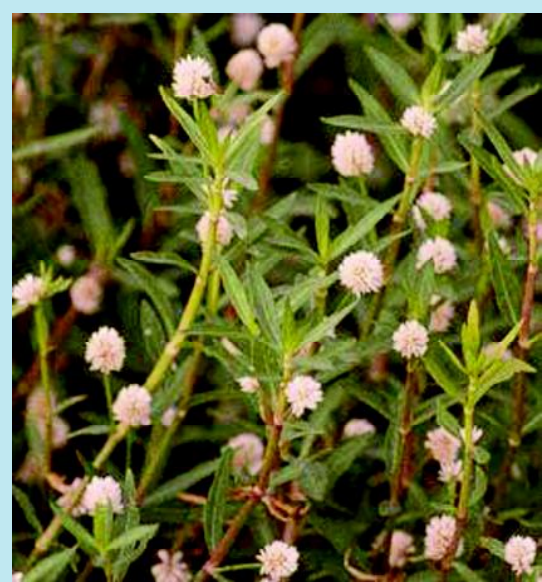

Alternanthera philoxeroides

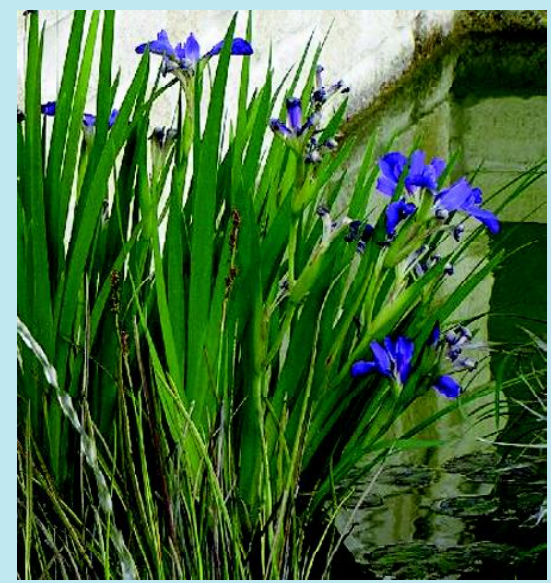

Iris sp.

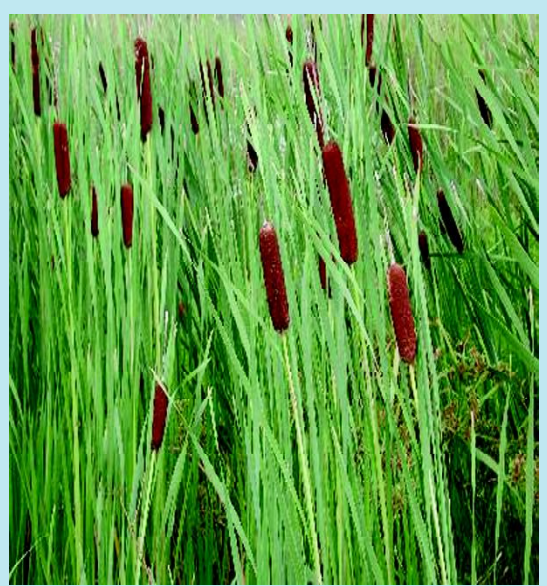

Typha sp.

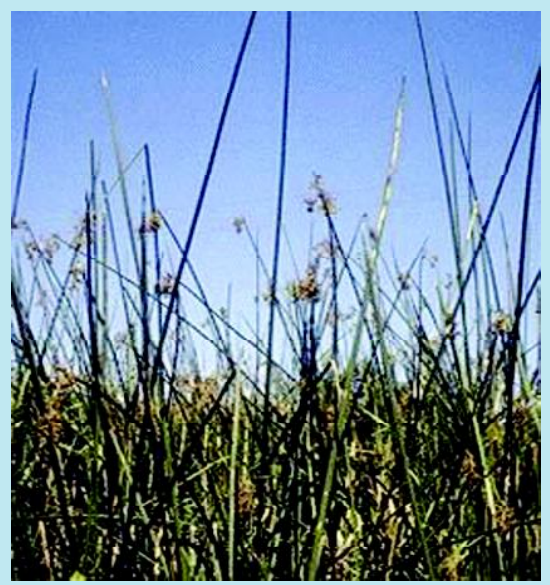

Scirpus sp.

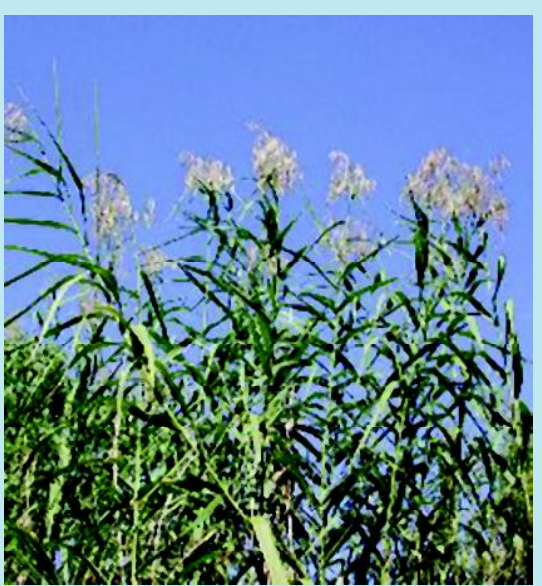

Phragmites sp.

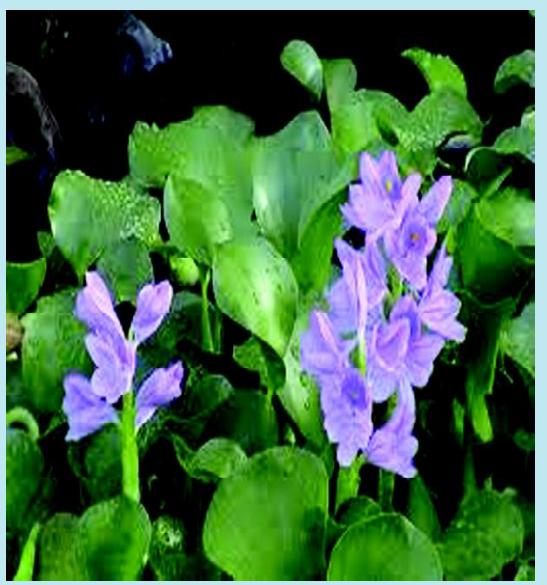

Eichhornia sp.

Sumber: http://aquaplant.tamu.edu/ dan http://www.aquagarden.com.ar

Gambar 3. Beberapa jenis tumbuhan air potensial untuk pengolahan limbah

Tabel 1. Jumlah elemen dari bahan cemaran yang dapat diserap oleh tumbuhan air (kg/ha/tahun)

\begin{tabular}{ccccc}
\hline Elemen & $\begin{array}{c}\text { Eichhornia } \\
\text { crassipes }\end{array}$ & $\begin{array}{c}\text { Justicia } \\
\text { americana }\end{array}$ & $\begin{array}{c}\text { Alternanthera } \\
\text { philoxeroides }\end{array}$ & $\begin{array}{c}\text { Typha } \\
\text { latifolia }\end{array}$ \\
\hline $\mathrm{N}$ & 1.980 & 2.290 & 1.780 & 2.630 \\
$\mathrm{P}$ & 320 & 140 & 200 & 400 \\
$\mathrm{~S}$ & 250 & 200 & 180 & 250 \\
$\mathrm{Ca}$ & 750 & 1.020 & 320 & 1.710 \\
$\mathrm{Mg}$ & 790 & 470 & 320 & 310 \\
$\mathrm{~K}$ & 3.190 & 3.720 & 3.220 & 4.570 \\
$\mathrm{Na}$ & 260 & 190 & 230 & 730 \\
$\mathrm{Fe}$ & 19 & 120 & 45 & 23 \\
$\mathrm{Mn}$ & 300 & 13 & 27 & 79 \\
$\mathrm{Zn}$ & 4 & 30 & 6 & 6 \\
$\mathrm{Cu}$ & 1 & 3 & 1 & 7 \\
\hline
\end{tabular}




\section{BEBERAPA APLIKASI CONSTRUCTED WETLAND UNTUK PENGOLAHAN AIR LIMBAH}

Sistem constructed wetland ini sudah banyak diterapkan di negara-negara maju maupun negara berkembang. Pada Gambar 4 dan Gambar 5 dapat dilihat beberapa contoh aplikasi constructed wetland untuk pengolahan air limbah di Thailand.

Saat ini penerapan sistem constructed wetland di Indonesia belum cukup berkembang. Namun berdasarkan informasi menurut Isa (2002) in Khiatuddin (2003), sistem ini sudah digunakan pada pengolahan limbah rumah tangga di sebuah pesantren di daerah Bandung, di mana air limbah di daur ulang dan dimanfaatkan kembali untuk menghasilkan sayuran dan ikan.

\section{LIMBAH BUDIDAYA IKAN}

Sumber utama dari limbah budidaya adalah dari sisa pakan yang tidak termakan, buangan dari proses metabolisme, pupuk, dan bibit penyakit (Khiatuddin, 2003; Millamena, 2002; Beveridge, 1987). Bahan-bahan tersebut dapat mempengaruhi pertumbuhan, metabolisme, imunitas dan produktivitas ikan budidaya. Komposisi limbah yang dihasilkan dari kegiatan budidaya perikanan di antaranya juga dipengaruhi oleh komposisi pakan ikan yang digunakan. Selain itu, jumlah limbah yang dihasilkan dari kegiatan budidaya sangat tergantung dari kualitas pakan dan manajemen pakan yang diterapkan.

Pakan merupakan sumber nutrien bagi pertumbuhan ikan, namun dapat menjadi sumber utama polutan bagi lingkungan budidaya. Millamnena (2002) menyebutkan bahwa unsur utama dari limbah pakan yang mempengaruhi lingkungan berupa nitrogen, fosfor, bahan organik, dan hidrogen sulfida. Sedangkan limbah budidaya secara keseluruhan terdiri atas : a) limbah padat, yang merupakan campuran dari pakan yang tidak termakan, feses, dan koloni bakteri, b) bahan terlarut, seperti amonia, urea, karbondioksida, fosfor, dan hidrogen sulfida.

Menurut Beveridge (1987), sedikit peningkatan laju suplai bahan organik ke sedimen dapat merangsang aktivitas bakteri, jamur, dan makro-invertebrata, yang

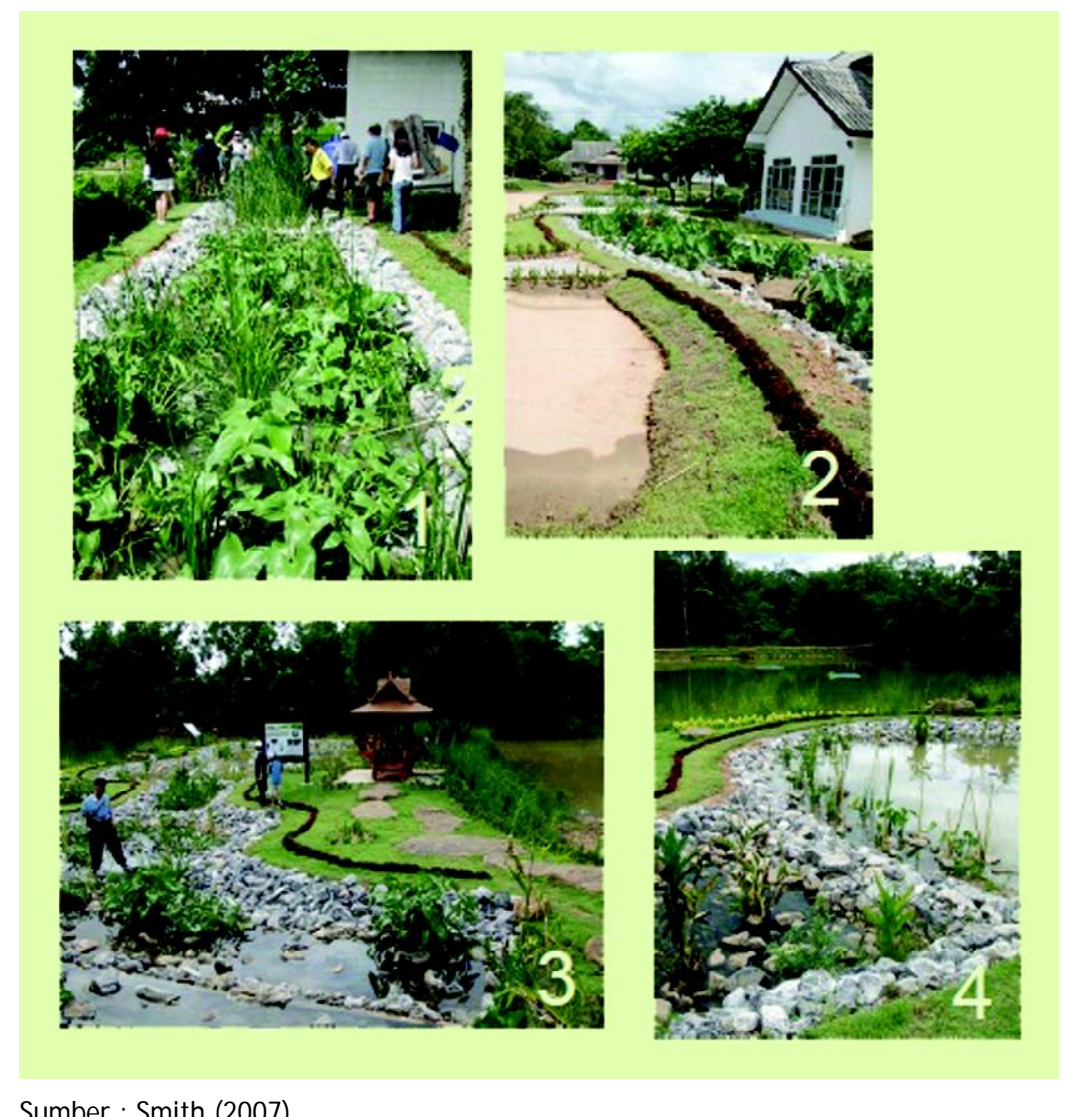

Sumber : Smith (2007)

Gambar 4. Penggunaan constructed wetland pada pengolahan air limbah dari pasar dan pemukiman masyarakat di Ubolratana (Thailand) yang terdiri atas 660 rumah penduduk dengan limbah $300 \mathrm{~m}^{3} /$ hari dan luas wilayah 4,9 hektar 


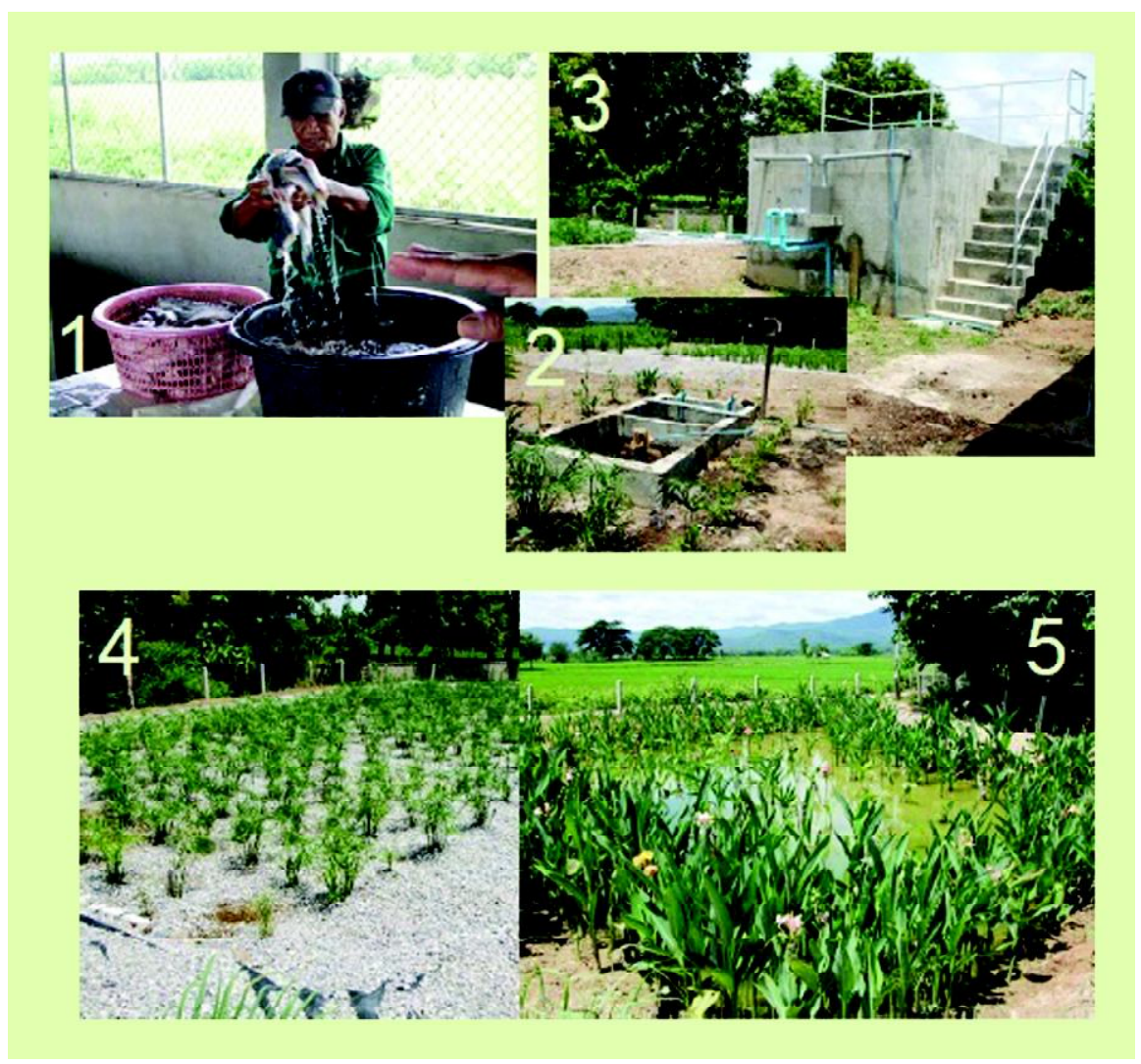

Sumber : Smith (2007)

Gambar 5. Penggunaan constructed wetland pada pengolahan air limbah dari daerah pengolahan ikan (fish processing) di Phayao (Thailand) yang terdiri atas 10 produsen produk olahan ikan dengan limbah 10 $\mathrm{m}^{3} /$ hari dan luas wilayah 0,15 hektar

kemudian dapat menyebabkan peningkatan kebutuhan oksigen oleh sedimen. Pada saat laju sedimentasi tinggi, laju suplai oksigen kemungkinan tidak dapat mencukupi kebutuhan komunitas mikrobial dan makro-bentik, yang mengakibatkan sedimen menjadi anoksik. Kemudian, bahan organik yang tersedimentasi di dasar perairan atau kolam akan terdekomposisi secara anaerob yang menghasilkan senyawa-senyawa toksik berupa $\mathrm{H}_{2} \mathrm{~S}$, gas methane, dan amonia.

Untuk mencegah timbulnya senyawa-senyawa toksik tersebut, salah satu alternatif yang dapat dilakukan untuk menanggulangi dan mengendalikan limbah dari kegiatan budidaya adalah dengan menerapkan sistem constructed wetland pada kolam-kolam budidaya ikan. Untuk penataan dan desainnya dapat disesuaikan dengan ketersediaan dan kondisi lahan, serta dengan mengikuti kriteria yang diperlukan dari sebuah constructed wetland. Sistem pengolahan limbah ini cukup efisien untuk diterapkan pada kolam-kolam budidaya. Berdasarkan penelitian Lin et al. (2002) in Khiatuddin (2003), penggunaan sistem constructed wetland di tambak ikan bandeng, di Taiwan berhasil menurunkan kadar partikel padat $47 \% 86 \%$ COD 25\% 55\%dan klorofil (dari fitoplankton) 76\% 95\%

\section{PENUTUP}

Sistem constructed wetland merupakan salah satu metode yang efektif untuk pengolahan air limbah, baik limbah organik maupun limbah yang mengandung unsur logam berat. Beberapa nilai positif yang dapat diperoleh dengan melakukan pengolahan limbah budidaya melalui sistem constructed wetland adalah tidak memerlukan biaya yang besar untuk pemeliharaan karena cukup dengan memanen/menyiangi daun-daun dari tumbuhan yang kering/layu. Selain itu, tumbuhan air tidak membutuhkan teknik pemeliharaan khusus, cukup aman digunakan karena tidak menggunakan bahan-bahan kimia yang dapat merusak lingkungan, air keluaran dari pengolahan dengan sistem tersebut dapat dimanfaatkan kembali, serta memberikan nilai estetika pada area budidaya dan pengolahan limbah tersebut. 


\section{DAFTAR ACUAN}

Anonimous. 1976. Making aquatic weeds useful: Some perspectives for developing countries. National Academy of Science. Washington, D.C., 174 pp.

Anonimous. 2003. Fitoremediasi: Upaya mengolah air limbah dengan media tanaman. 27 Oktober 2003. Departemen Permukiman dan Prasarana Wilayah. Jakarta.

Bensley, J.E. 2003. Constructed wetlands for stormwater management. Beals and Thomas, Inc. Resevoir Corporate Center. Southborough, Massachusetts.

Beveridge, M. 1987. Cage Aquaculture. Fishing News Books Ltd. England, 352 pp.

Boyd, C. E. 1970a. Chemical analysis of somevascular aquatic plants. Archievers of Hidrobiology, 67: 78-85.

Boyd, C.E. 1970b. Vascular aquatic plants for mineral nutrient removal from polluted waters. Econ. Bot., 24: 95- 103

Brown, S.L., Chaney, R.L., Angle, J.S. \& Baker, A.J.M. 1995. Zink and Cadmium uptake by hyperaccumulator Thlaspi caerulescens grown in nutrient solution. Soil Science Society of America J., 59: 125-133.

Crites, R.W., Gunther D.C., Kruzic, A.P., Pelz, J.D. \& Tchobanoglous, G. 1988. Design Manual: Constructed Wetlands and Aquatic Plant Systems for Municipal Wastewater Treatment. The U.S. Environmental Protection Agency (EPA). Center for Environmental Research Information (CERI). Cincinnati, Ohio, 83 pp.

Csurhes, S. \& Markula, A. 2010. Pest plant risk assessment: Alligator weed Alternanthera philoxeroides. Department of Employment, Economic Development and Innovation. The State of Queensland, 16 pp.
Department of Natural Resources-State of Georgia. 2002. Guidelines for Constructed Wetland for Municipal Wastewater Facilities. Georgia Environmental Protection Division. Georgia, 9 pp.

Khiatuddin, M. 2003. Melestarikan Sumber Daya Air Dengan Teknologi Rawa Buatan. Gadjah Mada University Press. Yogyakarta, $253 \mathrm{hlm}$.

Little, E.C.S. 1979. Handbook of utilization of aquatic plants. FAO Fisheries Technical Paper No. 187. Rome. Italy.

Mc Naughton, S.J. 1966. Ecotype function in the Typha community-type. Ecol. Monogr., 36: 297-325.

Millamena, O.M. 2002. Introduction to Nutrition in Tropical Aquaculture. Nutrition in Tropical Aquaculture: Essentials of Fish Nutrition, Feeds, and Feeding of Tropical Aquatic Species. SEAFDEC. Iloilo, Philippines, p. 1-5.

Moss, B. 1980. Ecology of freshwater. Blackwell Scientific Publication. Oxford.

Roberts, J. 1982. Production and demography in Typha orientalis. $21^{\text {st }}$ Annual Congres Australian Society for Limnology. Griffith, N.S.W., Cyclostyle (unpublished). $13 \mathrm{pp}$.

Smith, B.R. 2007. Constructed wetland for wastewater treatment : A planning \& design analysis for San Francisco. Department of City \& Regional Planning. Department of Landscape Architecture and Environmental Planning. UC Berkeley. Presented on September 10 $0^{\text {th }}, 2007$ (unpublished).

Widjaja, F. 2004. Tumbuhan Air. Fakultas Perikanan dan Ilmu Kelautan. Institut Pertanian Bogor, $58 \mathrm{hlm}$. 